\title{
Seasonal Variation in Fish Larvae at the Entrance of Guanabara Bay, Brazil
}

\author{
Marcia S. de Castro ${ }^{1 *}$, Ana Cristina Teixeira Bonecker ${ }^{1}$ and Jean L. Valentin ${ }^{2}$ \\ ${ }^{1}$ Departamento de Zoologia; ${ }^{2}$ Departamento de Biologia Marinha; Universidade Federal do Rio de Janeiro; CCS; \\ Bloco A; Ilha do Fundão; 21.941-590; Rio de Janeiro - RJ - Brazil
}

\begin{abstract}
Studies were carried out to find out qualitative and quantitative temporal variations in fish larvae to relate seasonal, diurnal and tidal cycles to the density of larvae. Sampling was performed at one station, during two three-day periods in September 1995 and March 1996. Samples were collected during ebb and flood tides,in oblique hauls using a bongo net of $500 \mu \mathrm{m}$ mesh size. A total of 42 taxa were identified. The families Engraulidae (Cetengraulis edentulus, Anchoa lyolepis) and Clupeidae (Harengula jaguana) had high mean densities and dominated both periods. Higher larval mean densities occurred in March, a period of relatively high temperatures and low salinities. The diurnal pattern of larval abundance consisted of high densities at night and low densities during the day. The observed diversity values stress the importance of this system for the maintenance of many species of fishes.
\end{abstract}

Key words: Fish larvae, seasonal variation, tidal cycle, diurnal variation, coastal bay, Guanabara Bay

\section{INTRODUCTION}

Coastal bays are large water bodies which can be more complex and variable than coastal estuaries (Kjerfve et al., 1997). Guanabara Bay in the state of Rio de Janeiro, Brazil, is classified as a coastal bay; however, it also contains regions, such as the inner part and the entrance channel that have typical estuarine features. Coastal systems such as bays, estuaries and lagoons play an important role in the reproduction, growth, and protection of many marine teleosts (Blaber and Blaber, 1980; Miller and Dunn, 1980; Haedrich, 1983; Olney and Boehlert, 1988; Boehlert and Mundy, 1988; Yoklavich et al., 1992; Monteleone, 1992). Many species spend their entire life cycles within estuaries, or recruit in these environments from coastal or offshore spawning grounds by passive tidal transport. Most commercially important fishes of the tropical and subtropical continental shelf depend on estuaries (Yáñez-Arancibia, 1986). An intensive energy exchange occurs between estuaries and coastal waters, because of transport of organic matter, nutrients, and organisms. These exchanges have focused scientific attention towards understanding the transport and recruitment mechanisms of fish larvae within estuarine environments (Norcross and Shaw, 1984; Shaw et al., 1988; Wang, 1988; Whitfield, 1989; Ré, 1990; Neira and Potter, 1992; Schwamborn and Bonecker, 1996).

Although Guanabara Bay has great socioeconomic and ecological importance, few studies about ichthyoplankton community have been developed (Kraus and Bonecker, 1994; Kraus, 1995; Bonecker, 1997), and the same has been

\footnotetext{
* Author for correspondence
} 
observed for adult community (Mazzetti and Hubold, 1982; Barroso, 1989; Tubino, 1996). The present study analyzed seasonal variation in abundance of fish larvae, and evaluated the influence of tidal and day/night cycles on larval density.

\section{STUDY AREA}

Guanabara Bay is located on the coast of the state of Rio de Janeiro (22 $50^{\circ} \mathrm{S}, 43^{\circ} 10^{\prime} \mathrm{W}$ ). The bay is $36 \mathrm{~km}$ long, with a mean depth of $7.6 \mathrm{~m}$, reaching $30 \mathrm{~m}$ in the entrance channel; the total water volume is $3 \times 10^{9} \mathrm{~m}^{3}$ (Amador, 1997). The estimated renewal time of $50 \%$ of the bay water volume is 11.4 days (Kjerfve et al., 1997). The region has semi diurnal tides, with low amplitude and $0.7 \mathrm{~m}$ of mean variation. Tidal currents account for most circulation within Guanabara Bay. Maximum currents in the channel attain 1.6 $\mathrm{m} . \mathrm{s}^{-1}$ near the entrance (FEEMA/JICA, 1994). The climate is humid-tropical (Kjerfve et al., 1997) with a warm rainy season (December through March) and a cool dry season (July through August) (Mayr et al., 1989; Paranhos and Mayr, 1993). The mean annual air temperature is 23.7 ${ }^{\circ} \mathrm{C}$; mean salinity in the bay ranges from 21.0 to $34.5 \%$ (Kjerfve et al., 1997). The bay is surrounded by one of the largest metropolitan area in Brazil, with more than 11 million inhabitants (FEEMA, 1990). The degraded bay environment can be divided into five sectors according to water quality, determined by pollution foci and circulation patterns (Villac et al., 1991). Water quality is poorest towards the inner bay, while the well-mixed channel area has the best water quality, where sampling was conducted.

\section{MATERIAL AND METHODS}

Sampling was done at one station in the entrance channel of Guanabara Bay $\left(22^{\circ} 54^{\prime} 44^{\prime \prime} S\right.$, $43^{\circ} 08^{\prime} 42^{\prime \prime} \mathrm{W}$ ); this area is influenced by coastal waters. Samplings were done during two periods, 13-15 September 1995 (dry season) and 13-15 March 1996 (rainy season) and 11-10 samples were collected respectively. Two replicate were done, representing a total of 42 ichthyoplankton samples. They were obtained during both ebb and flood tides along three days (each month), with 6 hours intervals in the syzygy period. Ichthyoplankton was collected by 10-minute oblique hauls using cylindrical-conical plankton nets (bongo net), each with a $60 \mathrm{~cm}$-diameter mouth and $500 \mu \mathrm{m}$ mesh. The maximum sampling depth was $25 \mathrm{~m}$. Flowmeters (Hydrobios and General Oceanics models) were fitted in the mouth of each net to determine the amount of water filtered per tow. Samples were preserved in $4 \%$ buffered formalin-seawater. Fish larvae were sorted from the catches using a binocular microscope (Zeiss model SV6) and were identified to the lowest possible taxonomic level. Densities of fish larvae were standardized according to the number collected per $100 \mathrm{~m}^{3}$ of filtered water. Salinity and temperature profiles were taken at one-meter intervals using a LabComp conductivity thermosalinometer. Only the surface and $20 \mathrm{~m}$ depth data were used in the present study.

\section{Data analysis}

The mean density of fish larvae in each sample collected at the same time (replicates) was estimated. Shannon's diversity index ( $\left.\mathrm{H}^{\prime}\right)$ and equitability (Evenness) were calculated to evaluate the degree of community organization during the two sampling periods. Densities differences among ebb and flood, and night and day in dry and rainy season were analyzed separately using nonparametric Kruskal-Wallis ANOVA (Siegel, 1975). All data were homogenized according to Ibanez (1976) by $\log (x+1)$.

\section{RESULTS}

\section{Hydrographic conditions}

Water temperature ranged between $22.5-24.5^{\circ} \mathrm{C}$ at the surface and $22.6-22.9^{\circ} \mathrm{C}$ at $20 \mathrm{~m}$ during September. Salinity values at surface $(32.0$ to $34.4 \%$ ) and at $20 \mathrm{~m}$ depth (32.4 to $34.5 \%$ ) were similar during all sampling. In September, the water column was considered homogeneous in terms of temperature and salinity. In March, water temperature varied from 26 to $28^{\circ} \mathrm{C}$ at the surface, and from 21.6 to $27.1^{\circ} \mathrm{C}$ at $20 \mathrm{~m}$. 
(a)

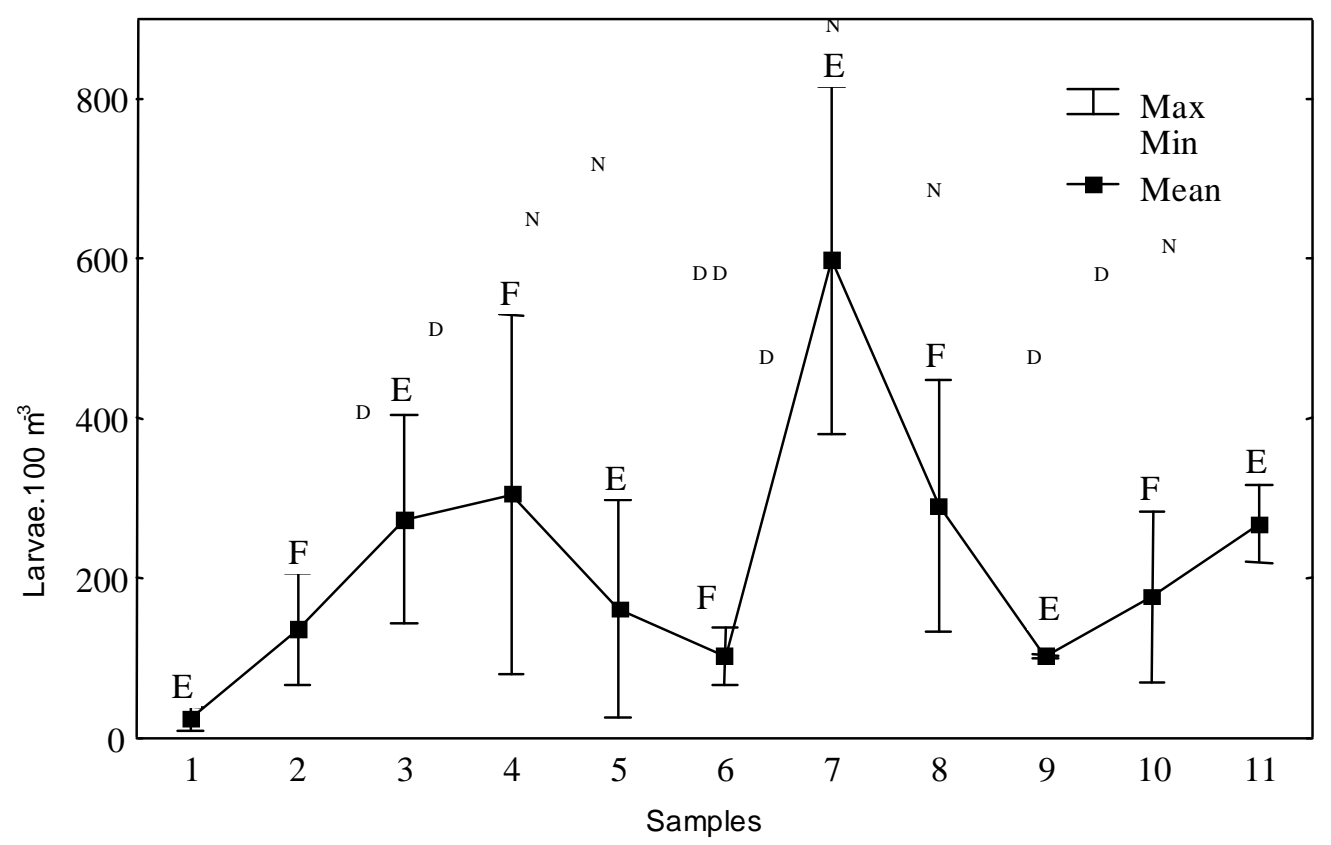

(b)

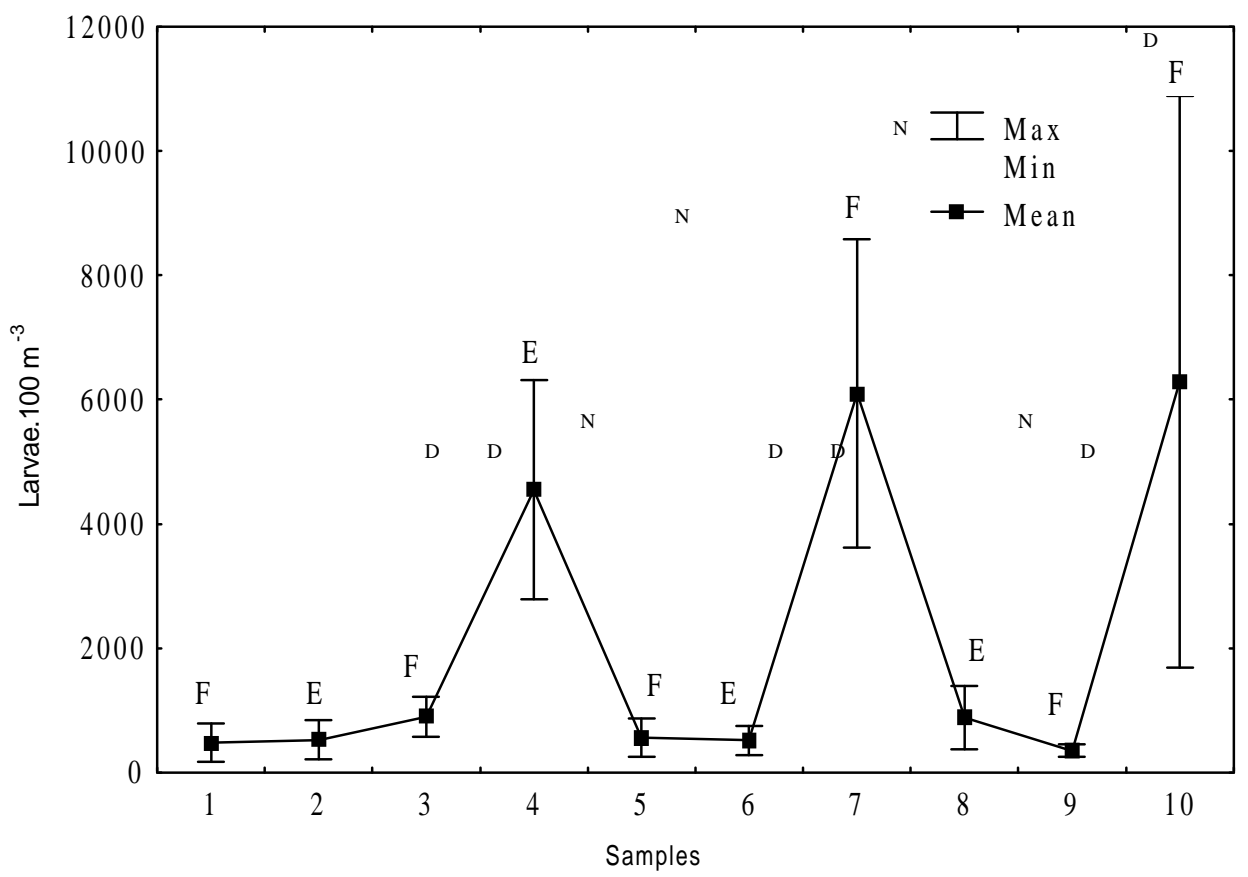

Figure 1 - Fish larvae mean density (larvae. $100 \mathrm{~m}^{-3}$ ) collected during September (a) and March (b) at the entrance of Guanabara Bay. The vertical bars are minimum and maximum values. $\mathrm{F}=$ flood tide; $\mathrm{E}=$ ebb tide; $\mathrm{D}=$ day; $\mathrm{N}=$ night. 
Salinity ranged from 26 to $29.5 \%$ at the surface and from 32.8 to $35.2 \%$, at $20 \mathrm{~m}$ depth. At this period, the surface water was less saline and warmer, while water at the $20 \mathrm{~m}$ depth was more saline and colder.

\section{Larvae fish mean densities}

During the dry season, mean densities of fish larvae ranged between 23.9 and 598.1 larvae.100 $\mathrm{m}^{-3}$ (Fig. 1a). In March, the mean densities were higher and ranged from 351 to 6,100 larvae.100 $\mathrm{m}^{-3}$ (Fig. 1b). Total larval densities in both sampling periods were higher during night and ebb tide (or early flood tide) and were lower during the day (Fig. 1).

Season $(\mathrm{KW}=25.21 ; \mathrm{p}=0.0002)$ and day/night variation $(\mathrm{KW}=8.4 ; \mathrm{p}=0.012)$ influenced significantly the fish larvae density. Although higher densities values were found during ebb tides, this factor did not influence significantly fish larvae density.

\section{Fish larvae occurrence and composition}

A total of 15,285 fish larvae comprising 42 taxa were caught. More species and genus were recorded in March (38) than in September (28). More demersal than pelagic families were represented. However, the latter group was more abundant, comprising $88 \%$ of the total catch in September and $94.5 \%$ in March.

Members of the family Engraulidae (Cetengraulis edentulus and Anchoa lyolepis) were the most abundant, comprising more than $80 \%$ of total larval numbers in both March and September. Clupeids (Harengula jaguana) represented more than $4.5 \%$ of the total. Members of the families Sciaenidae, Blenniidae, Gobiidae, and Ephippidae were also abundant. Members of other families comprised less than $5 \%$ of the total. Fish larvae which were damaged or in unidentifiable early life stages were grouped as "other", and contributed less than 3\%. Most taxa had higher mean densities during ebb tide and night sampling (Table 1).

During September, the diversity index was 2.87, while in March the index was 0.87 . Equitability values in September and March were 0.60 and 0.17 , respectively. These values reflected the dominance of such species as $C$. edentulus and $H$. jaguana in March.

Table 1 - Taxa caught in the entrance channel of Guanabara Bay during September/1995 and March/1996. Mean fish larvae densities (larvae. $100 \mathrm{~m}^{-3}$ ) in the ebb (E) and flood (F) tides and during day (D) and night (N) sampling.

\begin{tabular}{|c|c|c|c|c|c|c|c|c|}
\hline \multirow[t]{2}{*}{ Taxa } & ED & $\mathrm{EN}$ & FD & $\mathrm{FN}$ & ED & $\mathrm{EN}$ & FD & $\mathrm{FN}$ \\
\hline & \multicolumn{4}{|c|}{ September/1995 } & \multicolumn{4}{|c|}{ March/1996 } \\
\hline Ophichthus gomesii (d) & - & 1.3 & - & - & - & 2.7 & - & - \\
\hline Clupeidae (p) & - & 9.4 & - & 2.7 & 2.0 & - & - & - \\
\hline Harengula jaguana (p) & 9.6 & 43.3 & 32.0 & 16.2 & 263.4 & 410.0 & 99.2 & 256.4 \\
\hline Engraulidae (p) & 171.6 & 741.9 & 222.4 & 372.1 & 231.0 & 181.3 & 183.1 & 74.8 \\
\hline Cetengraulis edentulus (p) & 2.6 & 108.7 & 82.5 & 22.9 & $6,119.6$ & $4,556.4$ & 658.1 & $6,473.0$ \\
\hline Anchoa lyolepis (p) & 31.8 & 91.2 & 13.0 & 106.6 & 84.8 & 20.9 & 88.7 & 11.2 \\
\hline Hyporhamphus unifasciatus (p) & 0.6 & - & - & - & - & - & - & - \\
\hline Syngnathidae (d) & - & - & - & - & - & 2.7 & - & - \\
\hline Microphis brachyurus lineatus $(\mathrm{d})$ & - & 0.7 & 1.3 & - & - & 2.2 & - & - \\
\hline Syngnathus scovelli $(\mathrm{d})$ & 0.9 & 1.3 & - & - & 1.2 & - & - & 1.3 \\
\hline Hippocampus reidi $(\mathrm{d})$ & - & - & - & 0.5 & - & - & 0.8 & - \\
\hline Prionotus punctatus (d) & 0.9 & - & - & - & 8.5 & - & - & - \\
\hline Diplectrum radiale $(\mathrm{d})$ & - & - & - & - & - & - & 1.4 & - \\
\hline Rypticus randalli (d) & - & - & - & - & 3.1 & - & - & - \\
\hline Pomatomus saltatrix (p) & - & - & - & - & 3.1 & - & 0.8 & - \\
\hline Chloroscombrus chrysurus (p) & - & - & 2.7 & - & 65.7 & 44.5 & 34.7 & 24.7 \\
\hline Trachinotus carolinus (p) & - & - & - & - & 4.0 & - & 4.8 & - \\
\hline Selene vomer $(\mathrm{p})$ & - & - & - & - & 3.2 & 1.1 & 0.6 & - \\
\hline Decapterus punctatus (p) & - & - & - & - & - & - & 1.2 & - \\
\hline Lutjanus synagris $(\mathrm{d})$ & - & - & - & - & 2.8 & 3.4 & 1.1 & - \\
\hline Gerreidae (p) & 2.3 & - & 0.7 & 0.5 & 8.3 & 16.8 & 1.5 & 5.1 \\
\hline Diapterus sp. (p) & 1.5 & - & - & 0.5 & 5.8 & 1.1 & 3.1 & 3.5 \\
\hline Diapterus olisthostomus (p) & 0.9 & - & 0.5 & - & - & - & - & - \\
\hline Diapterus rhombeus (p) & 1.9 & - & 0.7 & 2.1 & - & - & - & - \\
\hline Eucinostomus sp. (p) & - & - & - & - & 1.3 & - & - & - \\
\hline Haemulidae (d) & 3.2 & 3.9 & 1.8 & 3.7 & 13.9 & 14.8 & 2.7 & 1.8 \\
\hline Archosargus rhomboidales (d) & - & - & - & - & 2.8 & - & - & - \\
\hline
\end{tabular}


Cont. Table 1

\begin{tabular}{|c|c|c|c|c|c|c|c|c|}
\hline Sciaenidae (d) & 1.7 & - & - & - & 3.3 & - & 4.5 & 7.5 \\
\hline Micropogonias furnieri (d) & 4.7 & 10.6 & 6.8 & - & 197.6 & 36.0 & 130.8 & 56.9 \\
\hline Stellifer rastrifer $(\mathrm{d})$ & 1.7 & 3.6 & 3.4 & - & 2.5 & - & 7.4 & 15.9 \\
\hline Menticirrhus americanus (d) & 0.9 & - & - & - & 6.2 & 5.9 & 6.3 & 5.5 \\
\hline Cynoscion sp. (d) & - & - & - & - & 0.8 & - & - & 4.1 \\
\hline Bairdiella ronchus $(\mathrm{d})$ & - & - & - & - & - & - & - & 1.8 \\
\hline Abudefduf saxatilis (p) & 2.4 & 0.7 & 2.0 & 1.2 & - & 8.7 & 10.1 & 3.2 \\
\hline Parablennius marmoreus (d) & 18.0 & 6.6 & 3.1 & 12.1 & - & 6.7 & 1.1 & - \\
\hline Parablennius pilicornis $(\mathrm{d})$ & 1.5 & 2.8 & 3.4 & 1.1 & 0.8 & 28.2 & 16.2 & 1.3 \\
\hline Hypleurochilus fissicornis (d) & & & & & 0.8 & - & - & - \\
\hline Gobiesox strumosus (d) & 6.7 & 4.3 & 12.9 & 1.2 & 7.5 & - & 5.1 & - \\
\hline Gobiidae (d) & 8.7 & 31.2 & 4.4 & 5.1 & 4.2 & 3.7 & 2.0 & - \\
\hline Gobionellus boleosoma (d) & - & 6.9 & 0.7 & 1.1 & - & 4.5 & - & 9.8 \\
\hline Microgobius meeki $(\mathrm{d})$ & - & 1.2 & - & - & - & - & - & - \\
\hline Trichiurus lepturus (p) & 2.9 & 3.9 & 1.9 & 1.2 & - & 2.2 & - & - \\
\hline Chaetodipterus faber (d) & 1.7 & - & - & - & 219.4 & 58.9 & 107.0 & 44.9 \\
\hline Citharichthys sp. (d) & - & - & - & - & 1.3 & - & - & - \\
\hline Etropus crossotus (d) & - & - & - & 2.4 & - & 3.4 & - & - \\
\hline Achirus lineatus (d) & 2.3 & 0.9 & 0.7 & 6.5 & 4.2 & 2.7 & 1.6 & - \\
\hline Symphurus plagusia (d) & - & - & - & - & - & - & 0.7 & 1.1 \\
\hline Monacanthus ciliatus (d) & - & - & 0.7 & - & - & - & - & - \\
\hline Acanthostracion quadricornis (d) & 0.6 & 0.9 & - & - & 4.3 & - & 5.2 & - \\
\hline Sphoeroides testudineus (d) & 2.4 & 11.2 & 8.1 & 2.8 & 12.8 & - & 3.9 & - \\
\hline Other & 4.1 & 53.1 & 9.5 & 32.9 & 39.0 & 16.1 & 10.0 & - \\
\hline Total & 288.1 & $1,139.6$ & 415.2 & 595.4 & $7,329.2$ & $5,434.9$ & $1,393.8$ & $7,003.8$ \\
\hline
\end{tabular}

$\mathrm{d}=$ demersal; $\mathrm{p}=$ pelagic

\section{DISCUSSION}

According to temperature and salinity results obtained in the present study, the entrance channel functioned as a partially mixed estuary during the dry season (September) and as a salt-wedge estuary in the rainy season (March). Nogueira et al. (1989) also found similar results during another study in Guanabara Bay. The species collected in the present study were all coastal fishes common in estuaries and other coastal regions of Brazil (Phonlor, 1973, 1975; Oliveira and Krau, 1976; Weiss, 1981; Sinque et al., 1982; Bonecker et al., 1991; Katsuragawa et al., 1993; Castro and Bonecker, 1996; Ibagy and Muelbert, 1997). In addition to the species identified in this study, members of the families Synodontidae, Exocoetidae, Mugilidae, Atherinidae, Fistularidae, Dactyloscopidae, Sphyraenidae, and Bothidae also occurred in Guanabara Bay (Bonecker, 1997).

The families Engraulidae and Clupeidae were the most abundant taxa in Guanabara Bay and were widespread on the southeastern coast of Brazil (Mazzetti and Hubold, 1982; Matsuura, 1983; Houde and Lovdal, 1984; Spach, 1990; Katsuragawa et al., 1993; Bonecker, 1997). High egg and larval densities of these families in Guanabara Bay, mainly during summer (Kraus and
Bonecker, 1994; Bonecker, 1997) could be related to the fact that some species have short life cycle and high reproductive capacity (Katsuragawa et al., 1993). Two engraulids were identified in the bay: the anchovy A. lyolepis that used coastal waters and Guanabara Bay as nurseries, and $C$. edentulus that completed its life cycle entirely within the bay (Mazzetti and Hubold, 1982). Among the clupeids found in the bay, H. jaguana seem to be the best-adapted species to this environment (Mazzetti and Hubold, 1982).

In Guanabara Bay entrance seasonality and day/night variation are the main factors that influence fish larvae density. Temperature increase is a controller of spawning and recruitment periods, because most species spawn during the summer months (Phonlor, 1984). Along the Brazilian coast, densities of fish larvae increase during summer (December to March) (Phonlor, 1973, 1984; Weiss, 1981; Sinque et al., 1982; Kraus, 1995; Katsuragawa et al., 1993; Castro and Bonecker, 1996; Bonecker, 1997). Because Guanabara Bay is situated in a tropical region, spawning occurs from January to April (Vazzoler, 1992), which is the hottest period of the year .

The higher larval densities recorded during night sampling at Guanabara Bay and in other studies (Bridger, 1956; Phonlor, 1973; Castro and 
Bonecker, 1996; Hettler et al., 1997) could be related to net avoidance by larger larvae during the day (Matsuura, 1977) and to vertical migration so that the larvae assembled near the bottom during the day and dispersed through the water column at night (Bridger, 1956; Bonecker et al., 2002). Other meroplanktonic organisms such as decapod larvae have a similar diurnal pattern in Guanabara Bay (Fernandes et al., 2002).

Although tide cycle did not influence significantly larval densities in the present study, higher values during ebb and early flood tide at night sampling, could be an indication that fish larvae be exported from the bay at this period. In Guanabara Bay, most larvae collected were at preflexion and flexion stages and had low swimming ability, suggesting a pattern of passive transport at the bay entrance. Small larvae are passively transported by the same processes as particle distribution (Ré, 1990), and depend on the net or residual circulation near the bay entrance and larval density (Wang, 1988). In estuaries strongly influenced by tidal currents, such as Guanabara Bay, the effects of tidal cycles on planktonic organisms are more evident. Although estuarine fish faunas tend to have low diversity (Haedrich, 1983; Ré, 1984), the index obtained for the entrance of Guanabara Bay is high (Bonecker, 1997) and typical of coastal regions (Margalef, 1983).

The dominance of Clupeidae and Engraulidae recorded in the bay probably accounted for the decrease in diversity, mainly during the summer when their abundance was higher. Dominance by relatively few groups was a common feature of the ichthyoplankton community (Katsuragawa et al., 1993), which might decrease the local community diversity (Ré, 1984). The large number of species collected in the bay entrance emphasized the importance of this environment as a nursery area for many species. In spite of increasing pollution, there were more than 125 species of fishes in the bay (FEEMA, 1990), and the coastal region supported an important fishery (Hubold and Gurgel, 1978).

\section{ACKNOWLEDGMENTS}

We thank the CNPq for financial support. We also thank Prof. Francisco Matos and all colleagues of the Integrated Zooplankton and Ichthyoplankton Laboratory of Biology Institute of Federal University of Rio de Janeiro for their assistance during the sampling. We extend our thanks to Dr. Janet W. Reid for reviewing the English text.

\section{RESUMO}

Devido a crescente ação antrópica a qual está sujeita e sua importância sócio-econômica, a baía de Guanabara vem despertando grande interesse na comunidade científica. $O$ presente trabalho objetivou analisar a variação quali-quantitativa temporal das larvas de peixes, relacionar a densidade das larvas com o ciclo nictemeral e verificar a influência dos ciclos de maré. Foram realizadas coletas, em um ponto localizado na entrada da baía, em setembro de 1995 e março de 1996. As coletas ocorreram nas marés de enchente e vazante ao longo de três dias. Os arrastos foram oblíquos, utilizando uma rede do tipo bongô com malhas de $500 \mu \mathrm{m}$. Foi coletado um total de 42 táxons. As famílias Engraulidae (Cetengraulis edentulus e Anchoa lyolepis) e Clupeidae (Harengula jaguana) ocorreram em grandes densidades e dominaram nas duas campanhas. As maiores densidades de larvas de peixes ocorreram durante a campanha de março, que apresentou altas temperaturas e baixas salinidades. Observouse um padrão nictemeral em relação a abundância de larvas, com altas densidades durante a noite e baixas durante o dia. Os altos índices de diversidade encontrados ressaltam a importância desse ecossistema para várias espécies de peixes.

\section{REFERENCES}

Amador, E. S. (1997), Baía de Guanabara $e$ Ecossistemas Periféricos: Homem e Natureza. Reproarte Gráfica e Editora Ltda. Rio de Janeiro.

Barroso, L. V. (1989), Diagnóstico Ambiental para Pesca de Águas Interiores no Estado do Rio de Janeiro. MINTER/IBAMA-RJ/ACUMEP, Rio de Janeiro.

Blaber, S. J. M and Blaber, T. G. (1980), Factors Affecting the Distribution of Juvenile Estuarine and Inshore Fish. Journal of Fish Biology, 17, 143-162.

Boehlert, G. W. and Mundy, B. C. (1988), Roles of Behavioral and Physical Factors in Larval and Juvenile Fish Recruitment to Estuarine Nursery Areas. American Fisheries Society Symposium, 3, 51-67. 
Bonecker, A. C. T.; Bonecker, S. L. C. and Bassani, C. (2002), Plâncton Marinho In: Pereira, R. C and Soares-Gomes, A. (Eds.). Biologia Marinha. Interciência. pp. 103-125.

Bonecker, A. C. T. (1997), Caracterização do Ictioplâncton na Entrada da Baía de Guanabara (RJ). PhD Thesis. Federal University of São Carlos.

Bonecker, S. L. C.; Bonecker, A. C. T.; Nogueira, C. R. and Reynier, M. V. (1991), Ecological Studies at Espírito Santo Bay, Brazil. Zooplankton Communities, pp. 3268-3278. In: Magoon, O. (Ed.). Coastal Zone 91, Publication American Society of Civil Engineers. v. 4.

Bridger, J. P. (1956), On Day and Night Variation in Catches of Fish Larvae. Journal Conseil, 22, 42-57.

Castro, M. S. and Bonecker, A. C. T. (1996), Ocorrência de Larvas de Peixes no Sistema Estuarino do Rio Mucuri. Arquivos de Biologia e Tecnologia, 39 : (1), 171-185.

FEEMA (1990), Projeto de Recuperação Gradual do Ecossistema da Baía de Guanabara - Indicadores Ambientais de Degradação Obras e Projetos de Recuperação. Parte I, Rio de Janeiro. 1-164.

FEEMA/JICA (1994), Fishes. In- The Study on Recuperation of the Guanabara Bay Ecosystem. Japan International Cooperation Agency ans Kokusai Kogyo Co., vol. 2, cap. 6.

Fernandes, L. D. A.; Bonecker, S. L. C. and. Valentin,. J. L. (2002), The Preliminary Dynamic of Decapod Crustacean Larvae in the entrance of Guanabara Bay. Brazilian Archives of Biology and Technology, 45, 491-498.

Haedrich, R. L. (1983), Estuarine Fishes,. In: Ketchum, B. H. (Ed.). Estuaries and Enclosed Seas Elseyies Publishing Company (Ecosystems of the World, 26). pp. 183-207.

Hettler Jr., W.; Peters, D. S.; Colby, D. R. and Laban,. E. H. (1997), Daily Variability in Abundance of Larval Fishes Inside Beaufort Inlet. Fishery Bulletin, 95, 477-493.

Houde, E. D. and Lovdal, J. A. (1984), Seasonality of Occurrence, Foods and Food Preferences of Ichthyoplankton in Biscayne Bay, Florida. Estuarine Coastal and Shelf Science, 18, 403-419.

Hubold, G. and Gurgel, I. M. (1978), Plankton Volumes, Temperature, and Salinity Distribution off Rio de Janeiro - Preliminary Results of the Cruise "Operação Rio de Janeiro". Instituto de Pesquisas da Marinha, 1-24.

Ibagy, A. S. and Muelbert, J. H. (1997), Condições Oceanográficas, Composição e Distribuição do Ictioplâncton da Lagoa dos Patos, RS, Brasil. VII Congresso Latino-Americano sobre Ciências do Mar, Santos. (abstract only). p. 20.

Ibanez, F. (1976), Contribution à l'analyse Mathématique des Évènements en Ecologie Planctonique. Bulletin de l'Institute Océanographique, 72 : (1431), 1-96.
Katsuragawa, M.; Matsuura, Y.; Suzuki, K.; Dias, J. F. and Spach, H. L. (1993), The Ichthyoplankton of the Ubatuba Region (São Paulo State, Brazil): Composition, Distribution and Seasonal Occurrence (1985-1988). Publicação Especial do Instituto Oceanográfico de São Paulo, 1 : (10), 85-121.

Kjerfve, B.; Ribeiro, C. H. A.; Dias, G. T. M.; Filippo, A. M. and Quaresma, V. da S. (1997), Oceanographic Characteristics of an Impacted Coastal Bay: Baía de Guanabara, Rio de Janeiro, Brazil. Continental Shelf Research, 17 : (13), 1-13.

Kraus, L. A. S. (1995), A Utilização do Geoprocessamento na Estimativa de Áreas com Potencial para Desova de Peixes e com Diferentes Qualidades de Água na Baía de Guanabara. MS Dissertation. Federal University of Rio de Janeiro.

Kraus, L. A. S. and Bonecker, A. C. T. (1994), The Spawning and Early Life Stages of Cetengraulis edentulus (Cuvier, 1824) (Pisces, Engraulidae) in a Fixed Point in Guanabara Bay (RJ - Brazil). Revista Brasileira de Biologia, 54 : (2), 199-209.

Margalef, R. (1983), Limnologia. Barcelona: Ediciones Omega S. A.

Matsuura, Y. (1977), O Ciclo de Vida da SardinhaVerdadeira (Introdução à Oceanografia Pesqueira). Publicação Especial do Instituto Oceanográfico de São Paulo, 4, 1-146.

Matsuura, Y. (1983), Estudo Comparativo das Fases Iniciais do Ciclo de Vida da Sardinha-verdadeira, Sardinella brasiliensis, e da Sardinha-cascuda, Harengula jaguana (Pisces: Clupeidae) e Nota sobre a Dinâmica da População de Sardinha-verdadeira na Região Sudeste do Brasil. São Paulo. (LivreDocência) São Paulo University.

Mayr, L. M.; Tenenbaum, D. R.; Villac, M. C.; Paranhos, R.; Nogueira, C. R.; Bonecker, S. L. C. and Bonecker, A. C. T. (1989), Hydrobiological Characterization of Guanabara Bay, In- Coastlines of Brazil eds. O. Magoon and C. Neves. American Society of Civil Engineers, New York. pp. 124-138.

Mazzetti, M. V. and Hubold, G. (1982), Growth, Morphometry and Aspects of Life History of the Scaled Sardine Harengula jaguana Pocy, 1865 in the Guanabara Bay (Brazil). Sonderdruck aus bd. 29 : (H. 2), 80-88.

Miller, J. M and Dunn, M. L. (1980), Feeding Strategies and Patterns of Movement in Juvenile Estuarine Fishes. In: Estuarine Perspective ed. V.S. Kennedy. Academic Press. pp. 437-481.

Monteleone, D. M. (1992), Seasonality and Abundance od Ichthyoplankton in Great South Bay, New York. Estuaries, 15 : (2), 230-238.

Neira, F. J. and Potter, I. C. (1992), Movement of Larval Fishes Through the Entrance Channel of a Seasonally Open Estuary in Western Australia. Estuarine, Coastal and Shelf Science, 35, 213-224. 
Nogueira, C. R.; Bonecker, A. C. T. and Bonecker, S. L. C. (1989), Zooplâncton da Baía de Guanabara (RJ-Brasil). Composição e Variações EspaçoTemporal. Memórias do III Encontro Brasileiro de Plâncton. pp. 151-156.

Norcross, B. L. and Shaw, R. F. (1984), Oceanic and Estuarine Transport of Fish Eggs and Larvae: A Review. Transactions of the American Fisheries Society, 113, 153-165.

Oliveira, L. P. H. and Krau, L. (1976), Estudos Aplicados a Recuperação da Baía de Guanabara. Memória do Instituto Oswaldo Cruz, 57(2), 115-125.

Olney, J. E. and Boehlert, G. W. (1988), Nearshore Ichthyoplankton Associated with Seagrass Beds in the Lower Cheasapeake Bay. Marine Ecology Progress Series, 45, 33-43.

Paranhos, R. and Mayr, L. M. (1993), Seasonal Patterns of Temperature and Salinity in Guanabara Bay, Brazil. Fresenius Environment Bulletin, 2, 647-652.

Phonlor, G. (1973), Estudo Preliminar do Ictioplâncton. In: Relatório sobre a Segunda Pesquisa Oceanográfica e Pesqueira do Atlântico Sul entre Torres e Maldonado (Lat $29^{\circ} \mathrm{S}-35^{\circ} \mathrm{S}$ ). Programa Rio Grande do Sul - II - Parte I. Publicação Especial do Instituto Oceanográfico de São Paulo, 3, 429-463.

Phonlor, G. (1975), Ictioplâncton da Região de Tramandaí e Adjacências. Documento Ocasional, 2, 5-45.

Phonlor, G. (1984), Morfologia e Biologia dos Ovos de Engraulidae do Sul do Brasil (Teleostei, Clupeiformes). Revista Brasileira de Biologia, 44 : (4), 467-487.

Ré, P. (1984), Ictioplâncton do Estuário do Tejo. Resultados de 4 Anos de Estudos (1978-1981). Arquivos do Museu Bocage (Série A), 2 : (9), 145-174.

Ré, P. (1990), Tidal Transport and Retention of Anchovy Eggs and Larvae within Mira Estuary (Portugal). Portugaliae Zoologica, 1 : (2), 7-13.

Schwamborn, R. and Bonecker, A. C. T. (1996), Seasonal Changes in the Transport and Distribution of Meroplankton into a Brazilian Estuary with Emphasis on the Transport of Floating Mangrove Leaves. Arquivos de Biologia e Tecnologia, 39 : (2), 451-462.

Shaw, R. F.; Rogers, B. D.; Cowan Jr., J. H. and Herke, W. H. (1988), Ocean-Estuary Coupling of Ichthyoplankton and Nekton in the Northern Gulf of Mexico. American Fisheries Society Symposium, 3, 77-89.

Siegel, S. (1975), Estatística Não-Paramétrica para as Ciências do Comportamento. São Paulo : McGraw-Hill.

Sinque, C.; Koblits, S. and Costa, L. M. (1982), Ictioplâncton do Complexo Estuarino-baía de Paranaguá e Adjacências $\left(25^{\circ} 10^{\prime} \mathrm{S}\right.$ - 25³5'S e $48^{\circ} 10^{\prime} \mathrm{W}$ - $\left.48^{\circ} 45^{\prime} \mathrm{W}\right)$, Paraná, Brasil - I - Aspectos Gerais. Arquivos de Biologia e Tecnologia, 25 : (3/4), 279-300.
Spach, H. L. (1990), Estudo Comparativo da Distribuição Espaço-Temporal e de Padrões de Agregação de Ovos e Larvas de Harengula jaguana, Sardinella brasiliensis (Clupeidae: Osteichthyes) e Engraulis anchoita (Engraulididae: Osteichthyes) na Costa Sudeste do Brasil. PhD Thesis. São Paulo University.

Tubino, R. A. (1996), Aspectos Reprodutivos da Savelha Brevoortia aurea (Agassiz, 1829), da Baía de Guanabara, Rio de Janeiro (Brasil). MS. Monograph. Federal University of Rio de Janeiro.

Vazzoler, A. E. A. M. (1992), Reprodução de Peixes, p. 1-11. In- A. A. Agostinho and E. Benedito-Cecílio (eds.), Situação Atual e Perspectivas da Ictiologia no Brasil. Editora da Universidade Estadual de Maringá.

Villac, M. C.; Mayr, L. M.; Tenenbaum, D. R.; Paranhos, R. (1991), Sampling Strategies Proposed to Monitor Guanabara Bay, RJ, Brazil. In: Magoon, O. T.; Converse, H. V.; Tippie, V.; Tobin, L. T. and Clarck, D. (Eds.). Coastal Zone'91., New York, American Society of Civil Engineers. pp. 1168-1182.

Wang, D. (1988), Transport Model for Water Exchange between Coastal Inlet and the Open Ocean. American Fisheries Society Symposium, 3, 9-15.

Weiss, G. (1981), Ictioplancton del Estuario de Lagoa dos Patos, Brazil. Argentina. PhD Thesis. Universidade Nacional de la Plata.

Whitfield, A. K. (1989), Ichthyoplankton Interchange in the Mouth Region of a Southern African Estuary. Marine Ecology Progress Series, 54, 25-33.

Yáñez-Arancibia, A. (1986), Ecologia da Zona Costeira. México, DF. AGT Editor, S.A.

Yoklavich, M. M.; Stevenson, M. and Cailliet, G. M. (1992), Seasonal and Spatial Patterns of Ichthyoplankton Abundance in Elkhorn Slough, California. Estuarine, Coastal and Shelf Science, 34/35, 1-21.

Received: April 11, 2003; Revised: January 30, 2004; Accepted: July 12, 2004. 